\title{
QUALIFICATION OF A CARBON ANALYZER TO SUPPORT THE DEFENSE WASTE PROCESSING FACILITY
}

M.T. Feller

T.B. Edwards

November 2010

Applied Computational Engineering and Statistics Savannah River National Laboratory

Aiken, SC 29808

This document was prepared in conjunction with work accomplished under Contract No. DE-AC09-08SR22470 with the U.S. Department of Energy. 
SRNL-STI-2010-00755

Revision 0

\section{DISCLAIMER}

This work was prepared under an agreement with and funded by the U.S. Government. Neither the U.S. Government or its employees, nor any of its contractors, subcontractors or their employees, makes any express or implied: 1 . warranty or assumes any legal liability for the accuracy, completeness, or for the use or results of such use of any information, product, or process disclosed; or 2. representation that such use or results of such use would not infringe privately owned rights; or 3. endorsement or recommendation of any specifically identified commercial product, process, or service. Any views and opinions of authors expressed in this work do not necessarily state or reflect those of the United States Government, or its contractors, or subcontractors.

This document was prepared in conjunction with work accomplished under Contract No. DE-AC09-08SR22470 with the U.S. Department of Energy. 
SRNL-STI-2010-00755

Revision 0

\section{REVIEWS AND APPROVALS}

\section{AUTHORS:}

M. T. Feller, Waste Laboratory Services

Date

Savannah River Remediation

T. B. Edwards, Applied Computational Engineering and Statistics

Date

Savannah River National Laboratory

\section{TECHNICAL REVIEWERS:}

D. R. Best, Process Technology Programs

Date

Savannah River National Laboratory

E. P. Shine, Applied Computational Engineering and Statistics Date

Savannah River National Laboratory

\section{APPROVERS:}

P. L. Lee, Manager, Applied Computational Engineering and Statistics Date Savannah River National Laboratory

C. C. Herman, Manager, Process Technology Programs

Date

Savannah River National Laboratory

R. T. McNew, Manager, Waste Laboratory Services

Date

Savannah River Remediation

J.E. Occhipinti, Manager, Waste Solidification Engineering

Date

Savannah River Remediation 


\section{EXECUTIVE SUMMARY}

The I-O Model 1030 carbon analyzer has been qualified for use at the Defense Waste Processing Facility (DWPF). The qualification was a side-by-side comparison of the Model 1030 system with the currently used Model 1010 Analyzer. This recommendation is based on side-by-side comparisons of the new unit to the currently used Model 1010 analyzer that are presented in this report. The side-byside testing included standards and process samples. The standards, which were used for instrument calibration verifications in the measurement of total inorganic carbon (TIC) and of total organic carbon (TOC), were traceable back to the National Institute of Standards and Technology. The process samples included TIC analyses of Sludge Receipt and Adjustment Tank samples and TOC analyses for Slurry Mix Evaporator (SME) samples.

After the Model 1030 has been used for production reporting, DWPF should consider an investigation into the uncertainties associated with the TOC measurements to determine how far below the 18,916 ppm limit DWPF must control the average of the measurements for a set of SME samples to account for the uncertainties of the measurements from this new analyzer. 


\section{TABLE OF CONTENTS}

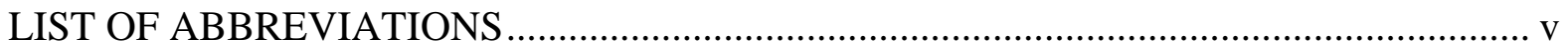

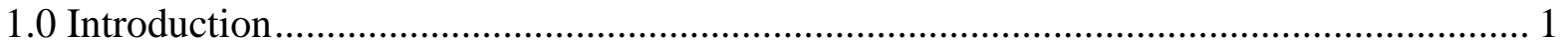

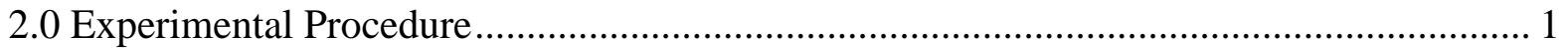

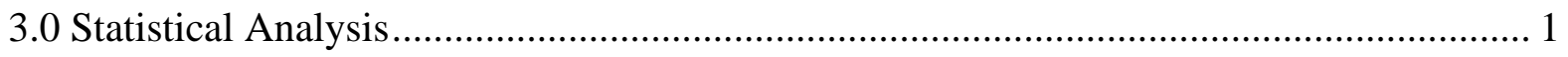

3.1 Initial Evaluations of Relative Bias between the Two Instruments.............................. 2

3.2 Initial Evaluations of the Precision of the Instruments................................................... 2

3.3 Additional Evaluations of Relative Bias between the Two Instruments ........................ 2

3.4 Additional Evaluations of Bias for Each of the Two Instruments............................... 3

3.5 Additional Evaluations of Bias for Each of the Two Instruments................................ 4

4.0 Conclusions and Recommendations ............................................................................ 4

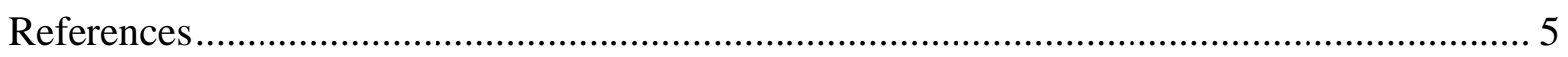

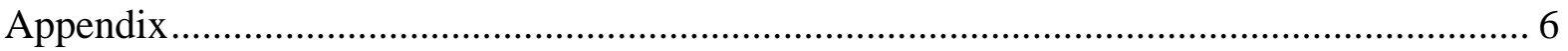

\section{LIST OF ABBREVIATIONS}

$\begin{array}{ll}\text { DWPF } & \text { Defense Waste Processing Facility } \\ \text { HLW } & \text { High Level Waste } \\ \text { JMP } & \text { Statistical software package from SAS Institute, Inc. [3] } \\ \text { LIMS } & \text { Laboratory Information Management System } \\ \text { NIST } & \text { National Institute of Standards and Technology } \\ \text { ppm } & \text { Parts per million } \\ \text { SME } & \text { Slurry Mix Evaporator } \\ \text { SRAT } & \text { Slurry Receipt and Adjustment Tank } \\ \text { SRNL } & \text { Savannah River National Laboratory } \\ \text { TTR } & \text { Technical Task Request } \\ \text { TT\&QA } & \text { Task Technical and Quality Assurance }\end{array}$




\subsection{INTRODUCTION}

The Savannah River Remediation (SRR) Defense Waste Processing Facility (DWPF) Laboratory currently utilizes a carbon analyzer, Model 1010, manufactured by O-I Analytical to perform total inorganic carbon (TIC) and total organic carbon (TOC) measurements on process samples. The results from these analyses are used by Waste Solidification Engineering (WSE) primarily as inputs to the DWPF acid equation and to ensure that melter flammability limits are not exceeded. The current analyzer, which has been in service for more than six years, needs to be replaced. A replacement unit (Model 1030 manufactured by O-I Analytical) has been purchased and installed at the DWPF Laboratory by Waste Laboratory Services (WLS). Before the new instrument is to be utilized for production reporting, its performance is to be evaluated and qualified relative to the performance of the current production unit. The WLS ran side-by-side comparisons of the old and new analyzers using standards and process samples at the DWPF Laboratory to generate the data for this evaluation.

DWPF issued a Task Technical Request [1] for SRNL to conduct a statistical evaluation of the sideby-side data to facilitate the qualification of the new carbon analyzer. Based upon the scope of this request, SRNL was to

1. perform a statistical review of the data to assess the performance of the new carbon analyzer.

2. review these results with WSE and WSL personnel,

3. participate in the decision to qualify the new instrument, and

4. document the results from this qualification effort in a technical report that describes the results and the conclusions from this study.

This report provides the data generated by WLS and the subsequent analyses conducted by SRNL and reviewed with WSE and WSL that led to the recommendation for the qualification of the new O-I Model 1030.

\subsection{Experimental Procedure}

Process samples from the Slurry Receipt and Adjustment Tank (SRAT) and the Slurry Mix Evaporator (SME) for several batches were analyzed by both the current and new instruments. The SRAT Receipt samples were analyzed for TIC and the SME samples for TOC. In addition to process samples, TIC standards at carbon concentrations of 1 and $20 \mathrm{ppm}$ and TOC standards at carbon concentrations of 1 and $20 \mathrm{ppm}$ were also prepared and analyzed for each of the two instruments. The standards are traceable back to the National Institute of Standards and Technology (NIST). The measurement data are provided in Table A1 of the Appendix, and they served as the basis for the comparisons between the two instruments that were conducted as part of this study. Exhibit A1 in the Appendix provides a plot of these measurements grouped by category (either check standard or process sample), type (for the check standards either $1 \mathrm{ppm}$ or $20 \mathrm{ppm}$ standards and for the process samples either SME or SRAT samples), measurement mode (either TIC or TOC), batch number, and Laboratory Information Management System (LIMS) number.

\subsection{Statistical Analysis}

In this section, the statistical comparisons of the measurements generated by the two carbon instruments are presented. JMP Version 7.0.2 [4] was used to perform these analyses. Of primary interest are investigations into any relative bias between the two measurement systems and into a 
comparison of their precisions. In addition, the measurements of the check standards from each instrument are investigated for a bias in their results.

\subsection{Initial Evaluations of Relative Bias between the Two Instruments}

Exhibit A2 in the Appendix provides an investigation into the relative bias between the two instruments using a paired-sample approach for the data of Table A1. The TIC and TOC measurements for check standards and process samples are considered in these analyses. None of these paired comparisons indicate a statistically significant bias, at the $5 \%$ level, between the two instruments. For the sake of consistency this paired approach was applied to all of the measurements in Table A1, but there is little correlation between the results for the two instruments for the check standards. Additional analyses of the measurements of the check standards are investigated in the discussion that follows.

\subsection{Initial Evaluations of the Precision of the Instruments}

Exhibit A3 in the Appendix provides an investigation into the precision of the two instruments using the measurement data of Table A1. In addition to a plot of the measurements for each instrument, there is a series of tests for equality of variance for the two sets of measurements. For this analysis, Levene's test will be used to make the comparisons of the precisions. If the "p-Value" for Levene's test comparing the variances of the measurements for the two instruments is less than or equal to 0.05, then the conclusion of the comparison is that there is a statistically significant difference, at the $5 \%$ level, in the variances. The conclusions from Exhibit A3 are that:

* For the 1 ppm check standards for TIC, the new model has a statistically significantly smaller measurement variance,

* For the $1 \mathrm{ppm}$ check standards for TOC, the new model has a statistically significantly smaller measurement variance,

* For the 20 ppm check standards for TIC, there is no statistically significant difference between the precisions of the two instruments,

* For the $20 \mathrm{ppm}$ check standards for TOC, there is no statistically significant difference between the precisions of the two instruments,

* For the SME samples for TOC, there is no statistically significant difference between the precisions of the two instruments, and

* For the SRAT samples for TIC, there is no statistically significant difference between the precisions of the two instruments.

Note that while this analysis was applied to all of the measurements from Table A1, the use of the measurements from the process samples was less than ideal since the sample to sample variation appears to be a dominant source of variation in these measurements. However, for the measurements available for this study, the precision of the new instrument, Model 1030, is at least as good as if not better than that of the current instrument, Model 1010. That is, there is no indication of a precision issue for the new instrument relative to the precision of the current instrument.

\subsection{Additional Evaluations of Relative Bias between the Two Instruments}

Exhibit A4 in the Appendix provides an investigation into the relative bias between the two instruments for the measurement data of Table A1 for the check standards. The TIC and TOC measurements for both the 1 and 20 ppm check standards are considered in these analyses. In this exhibit, the results from Levene's test are repeated, and they are used to indicate which t-test should be used to assess the statistically significance of the bias between the two instruments. The results from two t-tests are included in the exhibit. One t-test is appropriate if the variances of the two sets of 
measurements are equal and the other t-test is appropriate if the variances are unequal. The conclusions from Exhibit A4 are that:

* For the $1 \mathrm{ppm}$ check standards for TIC, the t-test for unequal variances is appropriate and from it, there is no indication of a statistically significant bias, at the $5 \%$ level, between the two instruments. In addition, the bound at $95 \%$ confidence on any potential bias is $0.047 \mathrm{ppm}$ (i.e., $4.7 \%)$.

* For the $1 \mathrm{ppm}$ check standards for TOC, the t-test for unequal variances is appropriate and from it, there is no indication of a statistically significant bias, at the $5 \%$ level, between the two instruments. In addition, the bound at $95 \%$ confidence on any potential bias is $0.124 \mathrm{ppm}$ (i.e., $12.4 \%$ ).

* For the 20 ppm check standards for TIC, the t-test for variances is appropriate and from it, there is no indication of a statistically significant bias, at the $5 \%$ level, between the two instruments. In addition, the bound at $95 \%$ confidence on any potential bias is $0.605 \mathrm{ppm}$ (i.e., $3.0 \%)$,

* For the 20 ppm check standards for TOC, the t-test for variances is appropriate and from it, there is a statistically significant bias, at the $5 \%$ level, between the two instruments. In addition, the bound at $95 \%$ confidence on this bias is $0.760 \mathrm{ppm}$ (i.e., $3.8 \%$ ).

Thus for these comparisons of relative bias between the two instruments, there does not appear to be any issues of practical concern.

\subsection{Additional Evaluations of Bias for Each of the Two Instruments}

Exhibit A5 in the Appendix provides an investigation into the bias of each of the two instruments using the measurement data of Table A1 for the check standards. The TIC and TOC measurements for both the 1 and 20 ppm check standards are considered in these analyses. In this exhibit, the results from JMP's descriptive statistics platform are provided for each set of data for each instrument. These results include a histogram of the data, quantiles, the mean, and the standard deviation as well as a 95\% confidence interval for the mean. In addition, a t-test is provided for each set of measurements for each instrument with the null hypothesis of the mean being the reference value for the standard. The conclusions from Exhibit A4 are that:

* For the 1 ppm check standards for TIC for Model 1010, the t-test for a mean of 1 ppm is rejected at the $5 \%$ significance level and the $95 \%$ confidence interval for the mean is given as $(1.016,1.102) \mathrm{ppm}$.

* For the 1 ppm check standards for TIC for Model 1030, the t-test for a mean of 1 ppm is rejected at the $5 \%$ significance level and the $95 \%$ confidence interval for the mean is given as $(1.040,1.074) \mathrm{ppm}$.

* For the 20 ppm check standards for TIC for the Model 1010, the t-test for a mean of 20 ppm is rejected at the $5 \%$ significance level and the $95 \%$ confidence interval for the mean is given as $(20.145,20.764) \mathrm{ppm}$.

* For the 20 ppm check standards for TIC for the Model 1030, the t-test for a mean of $20 \mathrm{ppm}$ is not rejected at the 5\% significance level and the $95 \%$ confidence interval for the mean is given as (19.935, 20.627) ppm.

* For the $1 \mathrm{ppm}$ check standards for TOC for Model 1010, the t-test for a mean of $1 \mathrm{ppm}$ is not rejected at the 5\% significance level and the 95\% confidence interval for the mean is given as (0.946, 1.119) ppm.

* For the 1 ppm check standards for TOC for Model 1030, the t-test for a mean of $1 \mathrm{ppm}$ is not rejected at the $5 \%$ significance level and the $95 \%$ confidence interval for the mean is given as (0.952, 1.044) ppm. 
* For the 20 ppm check standards for TOC for the Model 1010, the t-test for a mean of $20 \mathrm{ppm}$ is not rejected at the 5\% significance level and the $95 \%$ confidence interval for the mean is given as $(19.462,20.161) \mathrm{ppm}$.

* For the 20 ppm check standards for TOC for the Model 1030, the t-test for a mean of $20 \mathrm{ppm}$ is rejected at the $5 \%$ significance level and the $95 \%$ confidence interval for the mean is given as $(20.015,20.388) \mathrm{ppm}$.

Thus for these comparisons of bias for each of the two instruments, there does not appear to be any issues of practical concern.

\subsection{Additional Evaluations of Bias for Each of the Two Instruments}

One other conclusion from these comparisons between the two instruments is warranted. In 2003, Edwards [4] used available TOC measurement data, which had been generated by the DWPF Laboratory using the Model 1010 carbon analyzer, to estimate the uncertainties associated with TOC measurements. The purpose of that study was an investigation to determine how far below the 18,916 ppm limit DWPF must control the average of the measurements for a set of SME samples to account for the uncertainties of the measurements. That study concluded that using a control limit set at 5\% below the 18,916 ppm value provides a greater margin for error than required for the measurement uncertainties of the Model 1010 analyzer based upon the data and investigations presented in that study [4].

The limited TOC data available for the Model 1030 for this comparative study to Model 1010 precludes a revision of the uncertainty analysis of [4] as part of the effort presented here. However, the TOC results presented in this study indicate that the precision of the Model 1030 is as good as or better than the precision of the Model 1010 (see the results for comparisons of the TOC measurements in Exhibits A3 through A5). In each of these cases, the standard deviation of the Model 1030 TOC measurements is smaller than the standard deviation of the Model 1010 TOC measurements. However, it is recommended that DWPF consider evaluating results from the production use of the Model 1030 at some point in the future to revisit the uncertainty analysis presented in [4].

\subsection{CONCLUSIONS AND RECOMMENDATIONS}

Based upon the results presented in this report, it is recommended that the Model 1030 carbon analyzer is qualified for use. This recommendation is based on side-by-side comparisons of the new unit to the currently used Model 1010 analyzer that are presented in this report. The side-by-side testing included standards for instrument calibration verifications for TIC and TOC, and process samples. The standards were traceable back to NIST. The process samples included TIC analyses of SRAT Receipt samples and TOC analyses for SME samples.

At some point in the future, after the Model 1030 has been used for production reporting, DWPF should consider an investigation into the uncertainties associated with the TOC measurements to determine how far below the 18,916 ppm limit DWPF must control the average of the measurements for a set of SME samples to account for the uncertainties of the measurements from this new analyzer. 


\section{REFERENCES}

[1] Bricker, J.M., “Technical Task Request: Analyze Results for DWPF Laboratory Carbon Analyzer Qualification,” HLW-DWPF-TTR-2010-00034, August 8, 2010.

[2] Edwards, T.B., “Task Technical \& QA Plan: Analyze Results for DWPF Laboratory Carbon Analyzer Qualification,” SRNL-RP-2010-01273, Revision 0, August, 2010.

[3] JMP Version 7.0.2, SAS Institute, Inc., Cary NC, 1989-2007.

[4] Edwards, T.B., “Accounting for Uncertainties in DWPF's Measurement of Total Organic Carbon (U),” WSRC-TR-2003-00310, Revision 0, July 2003. 


\section{APPENDIX}

Table A1. Carbon Measurements (ppm) by Instrument

\begin{tabular}{|c|c|c|c|c|c|c|c|}
\hline Category & TYPE & MODE & ВАTCH & LIMS ID & Bottle ID & $\begin{array}{c}\text { Model } 1030 \\
\text { (ppm C) }\end{array}$ & $\begin{array}{c}\text { Model 1010 } \\
\text { (ppm C) }\end{array}$ \\
\hline sample results & SRAT-1 & TIC & 531 & 200000055 & 9473 & 2.628 & 2.519 \\
\hline sample results & SRAT-1 & TIC & 531 & 200000055 & 9474 & 2.576 & 2.586 \\
\hline sample results & SRAT-1 & TIC & 532 & 200001281 & 1306 & 1.898 & 1.737 \\
\hline sample results & SRAT-1 & TIC & 532 & 200001281 & 1307 & 2.353 & 2.244 \\
\hline sample results & SRAT-1 & TIC & 533 & 200001503 & 1116 & 2.258 & 2.041 \\
\hline sample results & SRAT-1 & TIC & 533 & 200001503 & 1119 & 2.244 & 2.169 \\
\hline sample results & SRAT-1 & TIC & 536 & 200002107 & 3214 & 2.369 & 2.266 \\
\hline sample results & SRAT-1 & TIC & 536 & 200002107 & 3217 & 2.373 & 2.419 \\
\hline sample results & SRAT-1 & TIC & 537 & 200002297 & 4183 & 2.274 & 2.252 \\
\hline sample results & SRAT-1 & TIC & 537 & 200002297 & 4182 & 2.631 & 2.724 \\
\hline sample results & SME-1 & TOC & 530 & 20074 & 1177 & 15.375 & 14.639 \\
\hline sample results & SME-1 & TOC & 530 & 20074 & 1178 & 15.537 & 15.385 \\
\hline sample results & SME-1 & TOC & 531 & 200001376 & 1414 & 15.337 & 14.848 \\
\hline sample results & SME-1 & TOC & 531 & 200001376 & 1415 & 16.447 & 16.561 \\
\hline sample results & SME-1 & TOC & 532 & 200001546 & 1734 & 14.932 & 15.008 \\
\hline sample results & SME-1 & TOC & 532 & 200001546 & 1737 & 14.175 & 14.433 \\
\hline sample results & SME-1 & TOC & 535 & 200002271 & 3990 & 17.587 & 17.581 \\
\hline sample results & SME-1 & TOC & 535 & 200002271 & 3991 & 16.371 & 17.232 \\
\hline check standard & 1ppm & TIC & 531 & 0 & 0 & 1.055 & 1.093 \\
\hline check standard & $20 \mathrm{ppm}$ & TIC & 531 & 0 & 0 & 20.75 & 19.817 \\
\hline check standard & $1 \mathrm{ppm}$ & TIC & 531 & 0 & 0 & 1.004 & 1.051 \\
\hline check standard & $20 \mathrm{ppm}$ & TIC & 531 & 0 & 0 & 20.938 & 20.33 \\
\hline check standard & $1 \mathrm{ppm}$ & TIC & 532 & 0 & 0 & 1.069 & 1.119 \\
\hline check standard & $20 \mathrm{ppm}$ & TIC & 532 & 0 & 0 & 19.904 & 19.854 \\
\hline check standard & $1 \mathrm{ppm}$ & TIC & 532 & 0 & 0 & 1.088 & 1.024 \\
\hline check standard & $20 \mathrm{ppm}$ & TIC & 532 & 0 & 0 & 20.956 & 20.195 \\
\hline check standard & $1 \mathrm{ppm}$ & TIC & 533 & 0 & 0 & 1.071 & 0.934 \\
\hline check standard & $20 \mathrm{ppm}$ & TIC & 533 & 0 & 0 & 20.16 & 20.92 \\
\hline check standard & $1 \mathrm{ppm}$ & TIC & 533 & 0 & 0 & 1.041 & 1.01 \\
\hline check standard & $20 \mathrm{ppm}$ & TIC & 533 & 0 & 0 & 19.953 & 20.938 \\
\hline check standard & $1 \mathrm{ppm}$ & TIC & 536 & 0 & 0 & 1.083 & 1.038 \\
\hline check standard & $20 \mathrm{ppm}$ & TIC & 536 & 0 & 0 & 20.098 & 20.303 \\
\hline check standard & $1 \mathrm{ppm}$ & TIC & 536 & 0 & 0 & 1.053 & 1.134 \\
\hline check standard & $20 \mathrm{ppm}$ & TIC & 536 & 0 & 0 & 20.566 & 20.594 \\
\hline check standard & $1 \mathrm{ppm}$ & TIC & 537 & 0 & 0 & 1.045 & 1.089 \\
\hline check standard & $20 \mathrm{ppm}$ & TIC & 537 & 0 & 0 & 19.6 & 20.571 \\
\hline check standard & $1 \mathrm{ppm}$ & TIC & 537 & 0 & 0 & 1.063 & 1.1 \\
\hline check standard & $20 \mathrm{ppm}$ & TIC & 537 & 0 & 0 & 19.885 & 21.027 \\
\hline check standard & $1 \mathrm{ppm}$ & TOC & 530 & 0 & 0 & 0.968 & 1.126 \\
\hline check standard & $20 \mathrm{ppm}$ & TOC & 530 & 0 & 0 & 20.34 & 19.367 \\
\hline check standard & $1 \mathrm{ppm}$ & TOC & 530 & 0 & 0 & 0.962 & 1.142 \\
\hline check standard & $20 \mathrm{ppm}$ & TOC & 530 & 0 & 0 & 20.37 & 19.394 \\
\hline check standard & $20 \mathrm{ppm}$ & TOC & 531 & 0 & 0 & 20.266 & 20.451 \\
\hline check standard & $1 \mathrm{ppm}$ & TOC & 531 & 0 & 0 & 1.09 & 1.061 \\
\hline check standard & $20 \mathrm{ppm}$ & TOC & 531 & 0 & 0 & 20.176 & 20.192 \\
\hline check standard & $1 \mathrm{ppm}$ & TOC & 532 & 0 & 0 & 0.958 & 1.075 \\
\hline check standard & $20 \mathrm{ppm}$ & TOC & 532 & 0 & 0 & 20.25 & 19.737 \\
\hline check standard & $1 \mathrm{ppm}$ & TOC & 532 & 0 & 0 & 0.962 & 0.979 \\
\hline check standard & $20 \mathrm{ppm}$ & TOC & 532 & 0 & 0 & 20.453 & 19.377 \\
\hline check standard & $1 \mathrm{ppm}$ & TOC & 535 & 0 & 0 & 1.033 & 0.946 \\
\hline check standard & $20 \mathrm{ppm}$ & TOC & 535 & 0 & 0 & 19.776 & 20.132 \\
\hline check standard & $1 \mathrm{ppm}$ & TOC & 535 & 0 & 0 & 1.013 & 0.896 \\
\hline check standard & $20 \mathrm{ppm}$ & TOC & 535 & 0 & 0 & 19.982 & 19.84 \\
\hline
\end{tabular}


Exhibit A1. Variability Chart for Carbon (ppm) Measurements

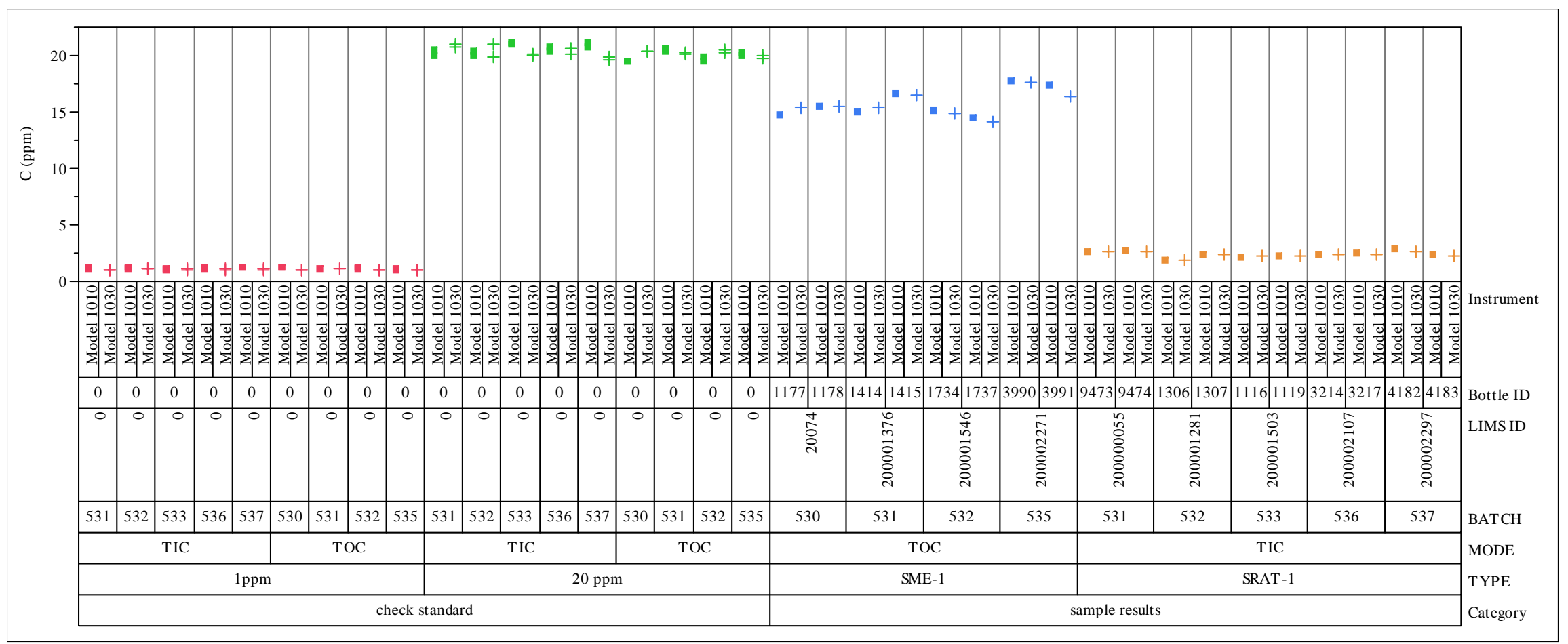




\section{Exhibit A2. Paired Comparisons of Measurement Data}

Matched Pairs Category=check standard, TYPE $=1 \mathrm{ppm}$, MODE $=$ TIC Difference: Model 1010 (ppm C)-Model 1030 (ppm C)

$\begin{array}{lrlr}\text { Model 1010 (ppm C) } & 1.0592 & \text { t-Ratio } & 0.09277 \\ \text { Model 1030 (ppm C) } & 1.0572 & \text { DF } & 9 \\ \text { Mean Difference } & 0.002 & \text { Prob }>|\mathrm{t}| & 0.9281 \\ \text { Std Error } & 0.02156 & \text { Prob }>\mathrm{t} & 0.4641 \\ \text { Upper95\% } & 0.05077 & \text { Prob }<\mathrm{t} & 0.5359 \\ \text { Lower95\% } & -0.0468 & & \\ \mathrm{~N} & 10 & & \\ \text { Correlation } & -0.1478 & & \end{array}$

Matched Pairs Category=check standard, TYPE $=20$ ppm, MODE=TIC Difference: Model 1010 (ppm C)-Model 1030 (ppm C)

$\begin{array}{lrlr}\text { Model 1010 (ppm C) } & 20.4549 & \text { t-Ratio } & 0.712787 \\ \text { Model 1030 (ppm C) } & 20.281 & \text { DF } & 9 \\ \text { Mean Difference } & 0.1739 & \text { Prob }>|t| & 0.4940 \\ \text { Std Error } & 0.24397 & \text { Prob }>\mathrm{t} & 0.2470 \\ \text { Upper95\% } & 0.7258 & \text { Prob }<\mathrm{t} & 0.7530 \\ \text { Lower95\% } & -0.378 & & \\ \text { N } & 10 & & \\ \text { Correlation } & -0.4157 & & \end{array}$

Matched Pairs Category=sample results, TYPE=SRAT-1, MODE=TIC Difference: Model 1010 (ppm C)-Model 1030 (ppm C)

$\begin{array}{lrlr}\text { Model 1010 (ppm C) } & 2.2957 & \text { t-Ratio } & -2.13705 \\ \text { Model 1030 (ppm C) } & 2.3604 & \text { DF } & 9 \\ \text { Mean Difference } & -0.0647 & \text { Prob }>|t| & 0.0613 \\ \text { Std Error } & 0.03028 & \text { Prob }>\mathrm{t} & 0.9693 \\ \text { Upper95\% } & 0.00379 & \text { Prob }<\mathrm{t} & 0.0307 \\ \text { Lower95\% } & -0.1332 & & \\ \mathrm{~N} & 10 & & \\ \text { Correlation } & 0.96038 & & \end{array}$

Matched Pairs Category=check standard, TYPE $=1 \mathrm{ppm}, \mathrm{MODE}=\mathrm{TOC}$ Difference: Model 1010 (ppm C)-Model 1030 (ppm C)

$\begin{array}{lrlr}\text { Model 1010 (ppm C) } & 1.03214 & \text { t-Ratio } & 0.757703 \\ \text { Model 1030 (ppm C) } & 0.998 & \text { DF } & 6 \\ \text { Mean Difference } & 0.03414 & \text { Prob }>|t| & 0.4773 \\ \text { Std Error } & 0.04506 & \text { Prob }>\text { t } & 0.2387 \\ \text { Upper95\% } & 0.1444 & \text { Prob }<\mathrm{t} & 0.7613 \\ \text { Lower95\% } & -0.0761 & & \\ \text { N } & 7 & & \\ \text { Correlation } & -0.3203 & & \end{array}$

Matched Pairs Category=check standard, TYPE $=20$ ppm, MODE $=$ TOC Difference: Model 1010 (ppm C)-Model 1030 (ppm C)

$\begin{array}{lrlr}\text { Model 1010 (ppm C) } & 19.8113 & \text { t-Ratio } & -1.93362 \\ \text { Model 1030 (ppm C) } & 20.2016 & \text { DF } & 7 \\ \text { Mean Difference } & -0.3904 & \text { Prob }>|t| & 0.0944 \\ \text { Std Error } & 0.20189 & \text { Prob }>\mathrm{t} & 0.9528 \\ \text { Upper95\% } & 0.08701 & \text { Prob }<\mathrm{t} & 0.0472 \\ \text { Lower95\% } & -0.8678 & & \\ \text { N } & 8 & & \\ \text { Correlation } & -0.546 & & \end{array}$

Matched Pairs Category=sample results, TYPE=SME-1, MODE=TOC Difference: Model 1010 (ppm C)-Model 1030 (ppm C)

$\begin{array}{lrlr}\text { Model 1010 (ppm C) } & 15.7109 & \text { t-Ratio } & -0.05422 \\ \text { Model 1030 (ppm C) } & 15.7201 & \text { DF } & 7 \\ \text { Mean Difference } & -0.0093 & \text { Prob }>|t| & 0.9583 \\ \text { Std Error } & 0.1706 & \text { Prob }>\mathrm{t} & 0.5209 \\ \text { Upper95\% } & 0.39417 & \text { Prob }<\mathrm{t} & 0.4791 \\ \text { Lower95\% } & -0.4127 & & \\ \text { N } & 8 & & \\ \text { Correlation } & 0.9231 & & \end{array}$




\section{Exhibit A3. Evaluation of Precision Using Measurement Data from the Check Standards}

Oneway Analysis of C (ppm) By Instrument Category=check standard, TYPE=1ppm, MODE=TIC

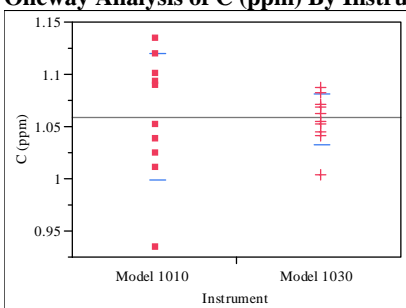

Tests that the Variances are Equal

Level Count Std Dev MeanAbsDif to Mean MeanAbsDif to Median

$\begin{array}{lrrrr}\text { Model } 1010 & 10 & 0.0602934 & 0.0478000 & 0.0478000\end{array}$

$\begin{array}{lrrrr}\text { Test } & \text { F Ratio } & \text { DFNum } & \text { DFDen } & \text { p-Value } \\ \text { O'Brien[.5] } & 2.9798 & 1 & 18 & 0.1014\end{array}$

$\begin{array}{lllll}\text { O'Brien[.5] } & 2.9798 & 1 & 18 & 0.1014 \\ \text { Brown-Forsythe } & 6.2128 & 1 & 18 & 0.0227 \\ \text { Lewente } & 6.8328 & 1 & 18 & 0.0176\end{array}$

$\begin{array}{lllll}\text { Brown-Forsythe } & 6.2128 & 1 & 18 & 0.0227 \\ \text { Levene } & 6.8328 & 1 & 18 & 0.0176 \\ \text { Bartlett } & 6.3281 & 1 & & 0.0119\end{array}$

F Test 2-sided $\quad 6.3281$

$9 \quad 0.0118$

Oneway Analysis of C (ppm) By Instrument Category=check standard, TYPE=20 ppm, MODE=TIC

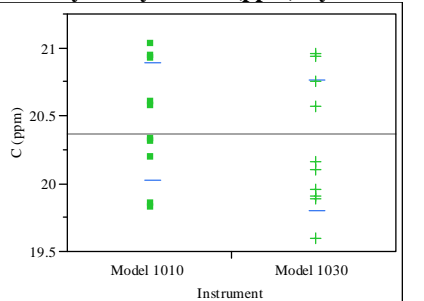

Tests that the Variances are Equal

Level Count Std Dev MeanAbsDif to Mean MeanAbsDif to Median

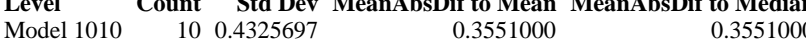

$\begin{array}{lllll}\text { Model } 1010 & 10 & 0.4325697 & 0.3551000 & 0.3551000 \\ \text { Model } 1030 & 10 & 0.4838365 & 0.4172000 & 0.3930000\end{array}$

$\begin{array}{lrrr}\text { Test } & \text { F Ratio DFNum DFDen p-Value } \\ \text { O'Brien[5] } & 0.2826 & 1\end{array}$

$\begin{array}{llll}0.2826 & 1 & 18 & 0.6015 \\ 0 & 1 & 18 & 0.7482\end{array}$

$\begin{array}{lllll}\text { Brown-Forsythe } & 0.1063 & 1 & 18 & 0.7482 \\ \text { Levene } & 0.4397 & 1 & 18 & 0.5157\end{array}$

$\begin{array}{llll}1 & 18 & 0.515 \\ 1 & -0.7439\end{array}$

$\begin{array}{lllll}\text { F Test 2-sided } & 1.2511 & 9 & \dot{9} & 0.7441\end{array}$
Oneway Analysis of C (ppm) By Instrument Category=check standard, TYPE=1ppm, MODE=TOC

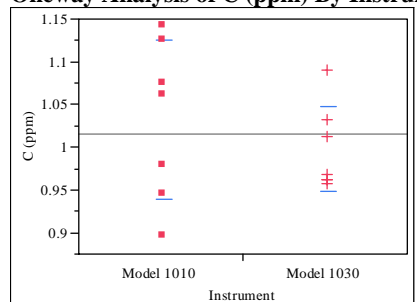

Tests that the Variances are Equal

Level Count Std Dev MeanAbsDif to Mean MeanAbsDif to Median

$\begin{array}{lllll}\text { Model } 1010 & 7 & 0.0933871 & 0.0786939 & 0.0765714 \\ \text { Model } 1030 & 7 & 0.0500100 & 0.0405714 & 0.0371429\end{array}$

Test F Ratio DFNum DFDen p-Value

$\begin{array}{lllll}\text { O'Brien[.5] } & 3.3965 & 1 & 12 & 0.0902 \\ \text { Brown-Forsyte } & 2.2519 & 1 & 12 & 0.1593\end{array}$

$\begin{array}{lllll}\text { Brown-Forsythe } & 2.2519 & 1 & 12 & 0.1593 \\ \text { Levene } & 4.8983 & 1 & 12 & 0.0470\end{array}$

$\begin{array}{lllll}\text { Levene } & 4.8983 & 1 & 12 & 0.0470 \\ \text { Bartlett } & 2.0329 & 1 & . & 0.1539\end{array}$

$\begin{array}{lllll}\text { F Test 2-sided } & 3.4871 & 6 & \dot{6} & 0.1540\end{array}$

Oneway Analysis of C (ppm) By Instrument Category=check standard, TYPE=20 ppm, MODE=TOC

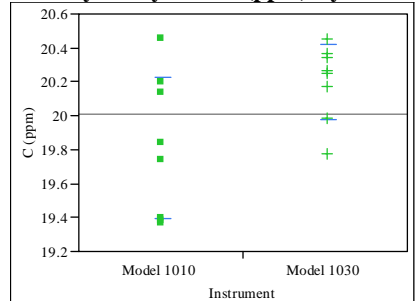

Tests that the Variances are Equal

Level Count Std Dev MeanAbsDif to Mean MeanAbsDif to Median

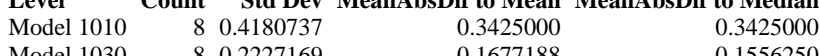

$\begin{array}{lrrrr}\text { Model } 1030 & 8 & 0.2227169 & 0.1677188 & 0.1556250\end{array}$

Test F Ratio DFNum DFDen p-Value

\begin{tabular}{lllll} 
O'Brien[.5] & 4.0287 & 1 & 14 & 0.0644 \\
\hline
\end{tabular}

$\begin{array}{lllll}\text { Brown-Forsythe } & 4.1780 & 1 & 14 & 0.0602 \\ \text { Lever } & 4.2008 & 1 & 14 & 0.0596\end{array}$

$\begin{array}{lllll}\text { Levene } & 4.2008 & 1 & 14 & 0.0596 \\ \text { Bartlett } & 2.4360 & 1 & & 0.1186\end{array}$

$\begin{array}{lllll}\text { F Test 2-sided } & 3.5237 & 7 & 7 & 0.1186\end{array}$ 


\section{Exhibit A3. Evaluation of Precision Using Measurement Data from the Check Standards}

Oneway Analysis of C (ppm) By Instrument Category=sample results, TYPE=SRAT-1, MODE=TIC

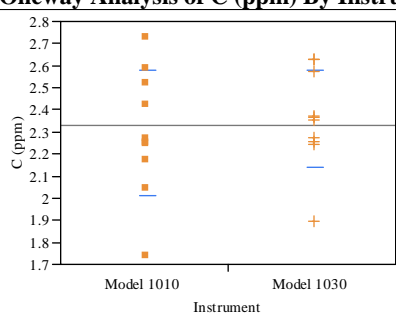

Tests that the Variances are Equal

Level Count Std Dev MeanAbsDif to Mean MeanAbsDif to Median

$\begin{array}{lrrrr}\text { Model } 1010 & 10 & 0.2850567 & 0.2130400 & 0.2071000\end{array}$

0.1550000

0.1550000

Test F Ratio DFNum DFDen p-Value

$\begin{array}{lllll}\text { O'Brien[.5] } & 0.5253 & 1 & 18 & 0.4779\end{array}$

Brown-Forsythe $0.4766-110180.4988$

$\begin{array}{lllll}\text { Levene } & 0.6394 & 1 & 18 & 0.4343\end{array}$

$\begin{array}{lllll}\text { Bartlett } & 0.5594 & 1 & \dot{0} & 0.4545 \\ \text { F Test 2-sided } & 1.6738 & 9 & 9 & 0.4547\end{array}$
Oneway Analysis of C (ppm) By Instrument Category=sample results, TYPE=SME-1, MODE=TOC

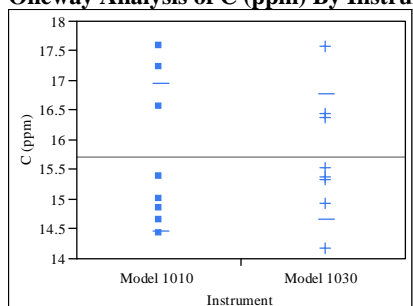

Tests that the Variances are Equal

Level Count Std Dev MeanAbsDif to Mean MeanAbsDif to Median

$\begin{array}{rrrrr}\text { Model } 1010 & 8 & 1.234074 & 1.060344 & 0.9788750 \\ \text { Model } 1030 & 8 & 1.051882 & 0.811156 & 0.7653750\end{array}$

Test F Ratio DFNum DFDen p-Value

$\begin{array}{lllll}\text { O'Brien[.5] } & 0.3180 & 1 & 14 & 0.5817\end{array}$

Brown-Forsythe $0.2924 \quad 11-14 \quad 0.5972$

$\begin{array}{lllll}\text { Levene } & 0.8384 & 1 & 14 & 0.3753 \\ \text { Bartlett } & 0.1660 & 1 & & 0.6837\end{array}$

$\begin{array}{lllll}\text { F Test 2-sided } & 1.3764 & 7 & 7 & 0.683\end{array}$ 
Exhibit A4. Evaluation of Relative Bias Using Measurement Data from the Check Standards

Oneway Analysis of C (ppm) By Instrument Category=check standard, TYPE=1ppm, MODE=TIC

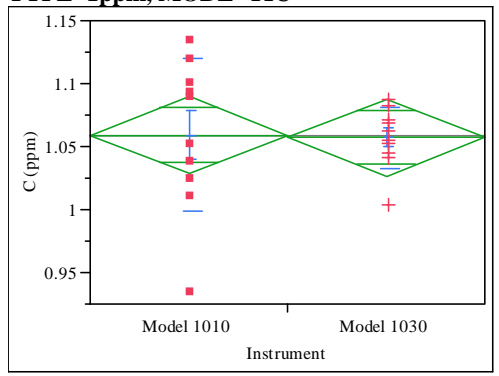

Oneway Anova

Summary of Fit

Rsquare

Adj Rsquare

0.000527

Root Mean Square Error

Mean of Resp

Observations (or Sum Wgts) $\quad 20$

t Test

Model 1030-Model 1010

Assuming equal variances

Difference $\quad-0.00200$ t Ratio $\quad-0.09739$

Std Err Dif $\quad 0.02054 \mathrm{DF} \quad 18$

Upper CL Dif 0.04115 Prob $>|t| 0.9235$

Lower CL Dif -0.04515 Prob $>\mathrm{t} \quad 0.5383$

$\begin{array}{lll}\text { Confidence } & 0.95 \text { Prob }<\mathrm{t} \quad 0.4617\end{array}$

Analysis of Variance

Source DF Sum of Squares Mean Square F Ratio Prob $>$ F

$\begin{array}{llllll}\text { Instrument } & 1 & 0.00002000 & 0.000020 & 0.0095 & 0.9235\end{array}$

$\begin{array}{llll}\text { Error } & 18 & 0.03795920 & 0.002109\end{array}$

C. Total $19 \quad 0.03797920$

Means for Oneway Anova

Level Number Mean Std Error Lower 95\% Upper 95\%

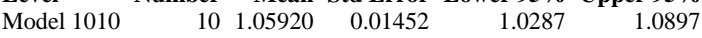

$\begin{array}{lllll}\text { Model } 1030 & 10 & 1.05720 & 0.01452 & 1.0267\end{array}$

Std Error uses a pooled estimate of error variance

Means and Std Deviations

Level Number Mean Std Dev Std Err Mean Lower 95\% Upper 95\%

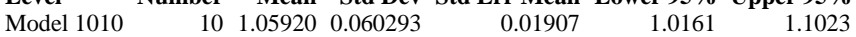

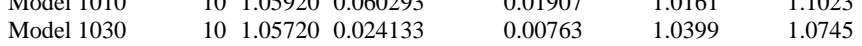

t Test

Model 1030-Model 1010

Assuming unequal variances

Difference $\quad-0.00200$ t Ratio $\quad-0.09739$

Std Err Dif $\quad 0.02054$ DF 11.81157

Upper CL Dif 0.04283 Prob $>|t| \quad 0.9241$

Lower CL Dif -0.04683 Prob $>t \quad 0.5380$

$\begin{array}{lr}\text { Confidence } & 0.95 \text { Prob }<\mathrm{t} \quad 0.4620\end{array}$

Tests that the Variances are Equal

Level Count Std Dev MeanAbsDif to Mean MeanAbsDif to Median

Model $1010 \quad 10 \quad 0.0602934$

$\begin{array}{lllll}\text { Model } 1030 & 10 & 0.0241330 & 0.0176000 & 0.0176000\end{array}$

Test F Ratio DFNum DFDen p-Value

O'Brien[.5]

Brown-Forsythe $\begin{array}{llll}6.2128 & 1 & 18 & 0.0227\end{array}$

$\begin{array}{lllll}\text { Levene } & 6.8328 & 1 & 18 & 0.0176\end{array}$

F Test 2-sided $\quad 6.2419 \quad 9 \quad 960118$
Oneway Analysis of C (ppm) By Instrument Category=check standard, TYPE=1ppm, MODE=TOC

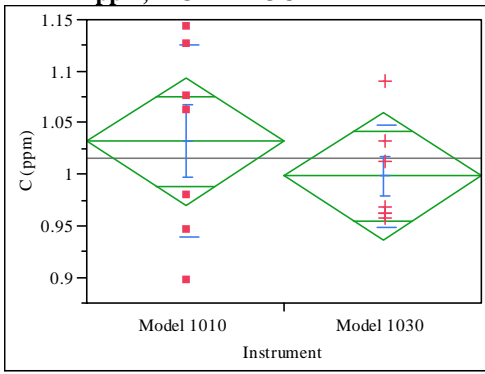

Oneway Anova

Summary of Fit

Rsquare $\quad 0.057134$

Adj Rsquare $\quad-0.0214$

Root Mean Square Error $\quad 0.074907$

Mean of Response 1.015071

Observations (or Sum Wgts) 14

t Test

Model 1030-Model 1010

Assuming equal variances

Difference $\quad-0.03414$ t Ratio -0.85273

Std Err Dif $\quad 0.04004$ DF 12

Upper CL Dif 0.05310 Prob $>|t| 0.4105$

Lower CL Dif -0.12138 Prob $>t \quad 0.7947$

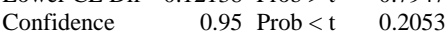

Analysis of Variance

Source DF Sum of Squares Mean Square F Ratio Prob $>$ F

$\begin{array}{llllll}\text { Instrument } & 1 & 0.00408007 & 0.004080 & 0.7271 & 0.4105\end{array}$

$\begin{array}{llll}\text { Error } & 12 & 0.06733286 & 0.005611\end{array}$

C. Total $13 \quad 0.07141293$

Means for Oneway Anova

Level Number Mean Std Error Lower 95\% Upper 95\%

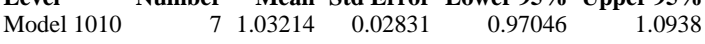

$\begin{array}{llllll}\text { Model } 1030 & 7 & 0.99800 & 0.02831 & 0.93631 & 1.0597\end{array}$

Std Error uses a pooled estimate of error variance

Means and Std Deviations

Level Number Mean Std Dev Std Err Mean Lower 95\% Upper 95\%

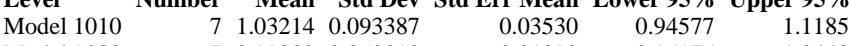

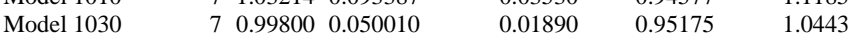

t Test

Model 1030-Model 1010

Assuming unequal variances

Difference $\quad-0.03414$ t Ratio $\quad-0.85273$

Std Err Dif $\quad 0.04004$ DF 9.179788

Upper CL Dif 0.05616 Prob $>|t| 0.4155$

Lower CL Dif -0.12445 Prob $>t \quad 0.7922$

$\begin{array}{lr}\text { Confidence } & 0.95 \text { Prob }<\mathrm{t} \quad 0.2078\end{array}$

Tests that the Variances are Equal

Level Count Std Dev MeanAbsDif to Mean MeanAbsDif to Median

$\begin{array}{lrrrr}\text { Model } 1010 & 7 & 0.0933871 & 0.0786939 & 0.0765714\end{array}$

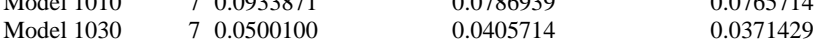

Test $\quad$ F Ratio DFNum DFDen p-Value

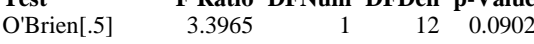

Brown-Forsythe $2.2519 \quad 1 \quad 12 \quad 0.1593$

$\begin{array}{lllll}\text { Levene } & 4.8983 & 1 & 12 & 0.0470\end{array}$

$\begin{array}{lllll}\text { Bartlett } & 2.0329 & 1 & 0.1539\end{array}$

$\begin{array}{lllll}\text { F Test 2-sided } & 3.4871 & 6 & 6 & 0.1540\end{array}$ 


\section{Exhibit A4. Evaluation of Relative Bias Using Measurement Data from the Check Standards}

Oneway Analysis of C (ppm) By Instrument Category=check standard, TYPE $=20$ ppm, MODE=TIC

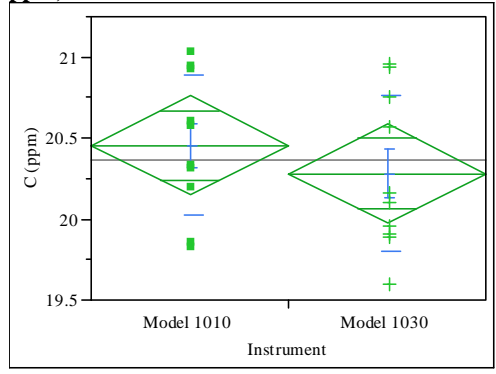

Oneway Anova

Summary of Fit

Rsquare $\quad 0.038356$

Adj Rsquare $\quad-0.01507$

Root Mean Square Error $\quad 0.45892$

Mean of Response 20.36795

Observations (or Sum Wgts) 20

t Test

Model 1030-Model 1010

Assuming equal variances

Difference $\quad-0.17390$ t Ratio $\quad-0.84732$

$\begin{array}{lrr}\text { Std Err Dif } & 0.20524 \text { DF } & 18\end{array}$

Upper CL Dif 0.25728 Prob $>|\mathrm{t}| \quad 0.4079$

Lower CL Dif -0.60508 Prob $>\mathrm{t} \quad 0.7960$

$\begin{array}{lll}\text { Confidence } & 0.95 \text { Prob }<\mathrm{t} \quad 0.2040\end{array}$

Analysis of Variance

Source DF Sum of Squares Mean Square F Ratio Prob $>$ F

$\begin{array}{llllll}\text { Instrument } & 1 & 0.1512060 & 0.151206 & 0.7180 & 0.4079\end{array}$

$\begin{array}{llll}\text { Error } & 18 & 3.7909289 & 0.210607\end{array}$

C. Total $19 \quad 3.9421349$

Means for Oneway Anova

Level Number Mean Std Error Lower 95\% Upper 95\%

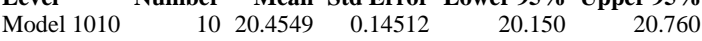

$\begin{array}{lllll}\text { Model } 1030 & 10 & 20.2810 & 0.14512 & 19.976 \\ 20.586\end{array}$

Std Error uses a pooled estimate of error variance

Means and Std Deviations

Level Number Mean Std Dev Std Err Mean Lower 95\% Upper 95\%

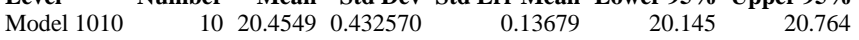

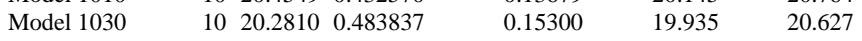

t Test

Model 1030-Model 1010

Assuming unequal variances

Difference $\quad-0.17390$ t Ratio $\quad-0.84732$

Std Err Dif $\quad 0.20524$ DF 17.77882

Upper CL Dif 0.25767 Prob $>|t| \quad 0.4081$

Lower CL Dif -0.60547 Prob $>t \quad 0.7960$

$\begin{array}{lll}\text { Confidence } & 0.95 \text { Prob }<\mathrm{t} \quad 0.2040\end{array}$

Tests that the Variances are Equal

Level Count Std Dev MeanAbsDif to Mean MeanAbsDif to Median

Model $1010 \quad 10 \quad 0.4325697$

$\begin{array}{lllll}\text { Model } 1030 & 10 & 0.4838365 & 0.4172000 & 0.3930000\end{array}$

Test F Ratio DFNum DFDen p-Value

$\begin{array}{lllll}\text { O'Brien[.5] } & 0.2826 & 1 & 18 & 0.6015\end{array}$

Brown-Forsythe $0.1063 \quad 1 \quad 18 \quad 0.7482$

$\begin{array}{lllll}\text { Levene } & 0.4397 & 1 & 18 & 0.5157\end{array}$

$\begin{array}{lllll}\text { F Test 2-sided } & 1.2511 & 9 & 9 & 0.7441\end{array}$
Oneway Analysis of C (ppm) By Instrument Category=check standard, TYPE $=20$ ppm, MODE $=$ TOC

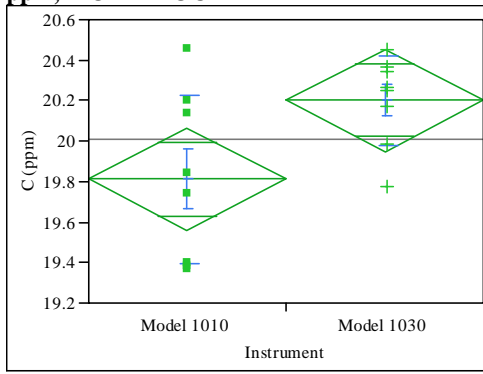

Oneway Anova

Summary of Fit

Rsquare $\quad 0.279582$

Adj Rsquare $\quad 0.22812$

Root Mean Square Error $\quad 0.334954$

Mean of Response 20.00644

Observations (or Sum Wgts) $\quad 16$

t Test

Model 1030-Model 1010

Assuming equal variances

Difference $\quad 0.390375$ t Ratio $\quad 2.330916$

Std Err Dif $\quad 0.167477$ DF $\quad 14$

Upper CL Dif 0.749578 Prob $>|\mathrm{t}| \quad 0.0352$

Lower CL Dif 0.031172 Prob $>t \quad 0.0176$

$\begin{array}{lll}\text { Confidence } & 0.95 \text { Prob }<\mathrm{t} \quad 0.9824\end{array}$

Analysis of Variance

Source DF Sum of Squares Mean Square F Ratio Prob $>$ F

$\begin{array}{llllll}\text { Instrument } & 1 & 0.6095706 & 0.609571 & 5.4332 & 0.0352\end{array}$

$\begin{array}{llll}\text { Error } & 14 & 1.5707194 & 0.112194\end{array}$

C. Total $15 \quad 2.1802899$

Means for Oneway Anova

Level Number Mean Std Error Lower 95\% Upper 95\%

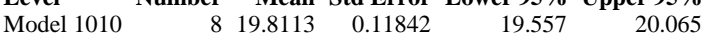

$\begin{array}{lllll}\text { Model } 1030 & 8 & 20.2016 & 0.11842 & 19.948\end{array} 20.456$

Std Error uses a pooled estimate of error variance

Means and Std Deviations

Level Number Mean Std Dev Std Err Mean Lower 95\% Upper 95\%

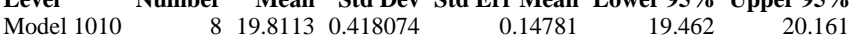

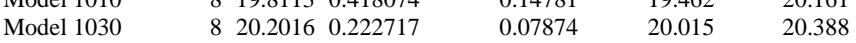

t Test

Model 1030-Model 1010

Assuming unequal variances

Difference $\quad 0.390375$ t Ratio 2.330916

Std Err Dif $\quad 0.167477$ DF $\quad 10.67696$

Upper CL Dif 0.760355 Prob $>|\mathrm{t}| \quad 0.0405$

Lower CL Dif 0.020395 Prob $>t \quad 0.0202$

$\begin{array}{lll}\text { Confidence } & 0.95 \text { Prob }<\mathrm{t} \quad 0.9798\end{array}$

Tests that the Variances are Equal

Level Count Std Dev MeanAbsDif to Mean MeanAbsDif to Median

$\begin{array}{lllll}\text { Model } 1010 & 8 & 0.4180737 & 0.3425000 & 0.3425000\end{array}$

$\begin{array}{llll}\text { Model } 1030 & 8 & 0.2227169 & 0.1677188\end{array}$

Test F Ratio DFNum DFDen p-Value

$\begin{array}{lllll}\text { O'Brien[.5] } & 4.0287 & 1 & 14 & 0.0644\end{array}$

Brown-Forsythe $\quad 4.1780 \quad 1 \quad 14 \quad 0.0602$

$\begin{array}{lllll}\text { Levene } & 4.2008 & 1 & 14 & 0.0596\end{array}$

$\begin{array}{lllll}\text { Bartlett } & 2.4360 & 1 & 0.1186\end{array}$

$\begin{array}{lllll}\text { F Test 2-sided } & 3.5237 & 7 & 7 & 0.1186\end{array}$ 


\section{Exhibit A5. Evaluation of Bias Using Measurement Data from the Check Standards}

Distributions Category=check standard, MODE=TIC, TYPE=1ppm, Instrument=Model 1010 C (

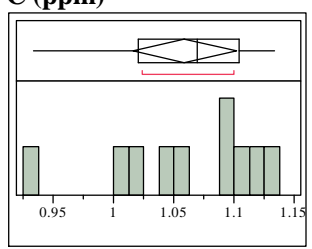

\section{Quantiles}

100.0\% maximum 1.1340 $99.5 \%$ 1.1340 $97.5 \% \quad 1.1340$

1.1325

$75.0 \%$ quartile 1.1048

$50.0 \%$ median 1.0700

$25.0 \%$ quartile 1.0205

$10.0 \% \quad 0.9416$

$2.5 \% \quad 0.9340$

$0.5 \% \quad 0.9340$

$0.0 \%$ minimum 0.9340

Moments

Mean $\quad 1.0592$

$\begin{array}{ll}\text { Std Dev } & 0.0602934\end{array}$

1.1023313

upper 95\% Mean 1.1023313

$\begin{array}{lr}\text { N } & 10\end{array}$

Test Mean=value

Hypothesized Value 1

Actual Estimate $\quad 1.0592$

$\begin{array}{lr}\text { df } & 9 \\ \text { Std Dev } & 0.06029\end{array}$

t Test

Test Statistic 3.1049

Prob $>|\mathrm{t}| \quad 0.0126$

Prob $>\mathrm{t} \quad 0.0063$

Prob $<\mathrm{t} \quad 0.9937$
Distributions Category=check standard, MODE=TIC, TYPE=1ppm, Instrument=Model 1030
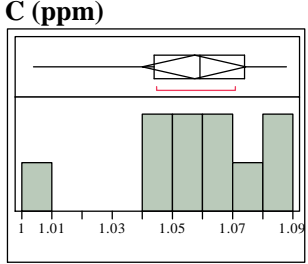

Quantiles

$100.0 \%$ maximum 1.0880

$99.5 \% \quad 1.0880$

$97.5 \% \quad 1.0880$

$90.0 \% \quad 1.0875$

$75.0 \%$ quartile 1.0740

$50.0 \%$ median 1.0590

$25.0 \%$ quartile 1.0440

$10.0 \% \quad 1.0077$

$2.5 \% \quad 1.0040$

$0.0 \%$ minimum 1.0040

Moments

Mean $\quad 1.0572$

Std Dev $\quad 0.024133$

076315

upper 95\% Mean 1.0744637

lower 95\% Mean 1.0399363

$\mathrm{N}$

Test Mean=value

Hypothesized Value 1

Actual Estimate

Std Dev $\quad 0.02413$

$\mathbf{t}$ Test
Test Statistic 7.4952

Prob $>|\mathrm{t}| \quad<.0001$

Prob $>\mathrm{t} \quad<.0001$

Prob $<\mathrm{t} \quad 1.0000$
Distributions Category $=$ check standard, MODE=TIC, TYPE $=20 \mathrm{ppm}$,

Instrument=Model 1010

C (ppm)

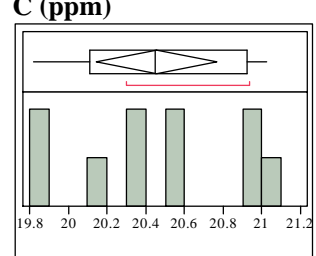

Quantiles

$100.0 \%$ maximum 21.027

$99.5 \% \quad 21.027$

$\begin{array}{ll}99.5 \% & 21.027\end{array}$

$90.0 \% \quad 21.018$

$75.0 \%$ quartile 20.925

$50.0 \%$ median 20.451

$25.0 \%$ quartile 20.110

$10.0 \% \quad 19.821$

$2.5 \% \quad 19.817$

$0.5 \% \quad 19.817$

$0.0 \%$ minimum 19.817 Moments

Mean 20.4549

$\begin{array}{ll}\text { Std Dev } & 0.4325697 \\ \text { Std Err Mean } & 0.1367905\end{array}$

upper $95 \%$

N $\quad 10$

Test Mean=value

Hypothesized Value 20

Actual Estimate $\quad 20.4549$

Std Dev $\quad 0.43257$

$\begin{array}{lr} & \mathbf{t} \text { Test } \\ \text { Test Statistic } & 3.3255 \\ \text { Prob }>|\mathrm{t}| & 0.0089 \\ \text { Prob }>\mathrm{t} & 0.0044 \\ \text { Prob }<\mathrm{t} & 0.9956\end{array}$

Distributions Category=check standard, MODE=TIC, TYPE $=20 \mathrm{ppm}$

Instrument=Model 1030

C (ppm)

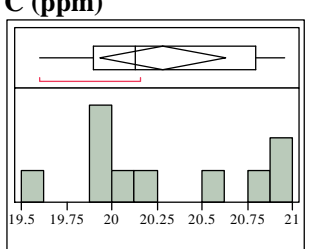

Quantiles

$100.0 \%$ maximum 20.956

$99.5 \% \quad 20.956$

$97.5 \% \quad 20.956$

$90.0 \% \quad 20.954$

$75.0 \%$ quartile 20.797

$50.0 \%$ median 20.129

$25.0 \%$ quartile 19.899

$10.0 \% \quad 19.629$

$2.5 \% \quad 19.600$

$0.0 \%$ minimum 19.600

Moments

Mean 20.28

$\begin{array}{ll}\text { Std Dev } & 0.4838365 \\ \text { Std Err Mean } & 0.1530025\end{array}$

upper 95\% Mean 20.627116

lower 95\% Mean 19.934884

$\mathrm{N}$

Test Mean=value

Hypothesized Value $\quad 20$ Actual Estimate $\quad 20.281$

Std Dev

9
0.48384

\section{t Test}

Test Statistic 1.8366

Prob $>|\mathrm{t}| \quad 0.0995$

Prob $>\mathrm{t} \quad 0.0497$

Prob $<\mathrm{t} \quad 0.9503$ 


\section{Exhibit A5. Evaluation of Bias Using Measurement Data from the Check Standards}

Distributions Category=check standard, MODE=TOC, TYPE $=1 \mathrm{ppm}$ Instrument=Model 1010 C (ppm)

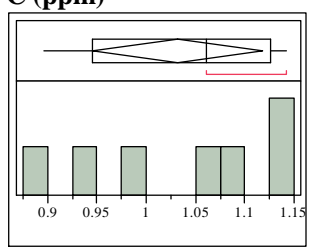

\section{Quantiles}

$100.0 \%$ maximum 1.1420

$99.5 \%$

1.1420
1.1420

$97.5 \%$

1.1420

$75.0 \%$ quartile 1.1260

$50.0 \%$ median 1.0610

$25.0 \%$ quartile $\quad 0.9460$

$10.0 \% \quad 0.8960$

$2.5 \% \quad 0.8960$

$0.5 \% \quad 0.8960$

$0.0 \%$ minimum 0.8960

Moments

$\begin{array}{ll}\text { Mean } & 1.0321429 \\ \text { Std Dev } & 0.0933871\end{array}$

Std Err Mean $\quad 0.035297$

upper $95 \%$ Mean 1.1185115

lower 95\% Mean 0.9457742

lower 95\% Mean 0.9457742

Test Mean=value

Hypothesized Value 1

Actual Estimate 1.03214

Std Dev $\quad 0.09339$

$t$ Tes

Test Statistic 0.9106

Prob $>|t| \quad 0.3976$

Prob $>\mathrm{t} \quad 0.1988$

Prob $<\mathrm{t} \quad 0.8012$
Distributions Category=check standard, MODE=TOC, TYPE $=1 \mathrm{ppm}$, Instrument=Model 1030

C (ppm)

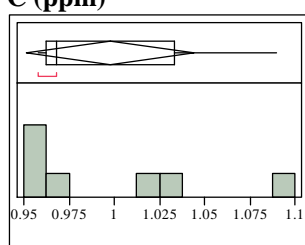

Quantiles

$100.0 \%$ maximum 1.0900

$99.5 \% \quad 1.0900$

$\begin{array}{ll}99.5 \% & 1.0900 \\ 97.5 \% & 1.0900\end{array}$

$90.0 \% \quad 1.0900$

$75.0 \%$ quartile 1.0330

$50.0 \%$ median 0.9680

$25.0 \%$ quartile 0.9620

$10.0 \% \quad 0.9580$

$2.5 \% \quad 0.9580$

$0.5 \% \quad 0.9580$

$0.0 \%$ minimum 0.9580

Moments

Mean $\quad 0.998$

$\begin{array}{lr}\text { Std Dev } & 0.05001 \\ \text { Std Err Mean } & 0.018902\end{array}$

0.018902

upper $95 \%$ Mean 1.0442515

lower $95 \%$ Mean 0.9517485

Test Mean=value

$\begin{array}{lr}\text { Hypothesized Value } & 1 \\ \text { Actual Estimate } & 0.998\end{array}$

6

Std Dev

0.05001

t Test

Test Statistic -0.1058

Prob $>|t| \quad 0.9192$

Prob $>\mathrm{t} \quad 0.5404$
Distributions Category=check standard, MODE $=$ TOC, TYPE $=20 \mathrm{ppm}$,

Instrument=Model 1010

C (ppm)

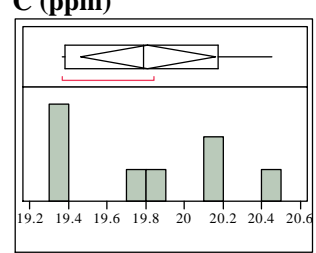

\section{Quantiles}

$100.0 \%$ maximum 20.451

$99.5 \% \quad 20.451$

$\begin{array}{ll}97.5 \% & 20.451\end{array}$

$90.0 \% \quad 20.451$

$75.0 \%$ quartile 20.177

$50.0 \%$ median 19.789

$25.0 \%$ quartile 19.38

$10.0 \% \quad 19.367$

$\begin{array}{ll}2.5 \% & 19.367\end{array}$

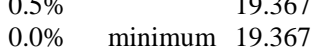

$0.0 \%$ min
Moments

Mean $\quad 19.81125$

Std Dev $\quad 0.4180737$

Std Err Mean $\quad 0.147811$

upper 95\% Mean 20.160768

lower 95\% Mean 19.461732

$\mathrm{N}$

Test Mean=value

Hypothesized Value 20

Actual Estimate 19.8113

Std Dev

0.41807

$\begin{array}{lr} & \mathbf{t} \text { Test } \\ \text { Test Statistic } & -1.2770 \\ \text { Prob }>|t| & 0.2423 \\ \text { Prob }>t & 0.8788 \\ \text { Prob }<\text { t } & 0.1212\end{array}$
Distributions Category=check standard, MODE $=$ TOC, $T Y P E=20 \mathrm{ppm}$,

Instrument=Model 1030

C (ppm)

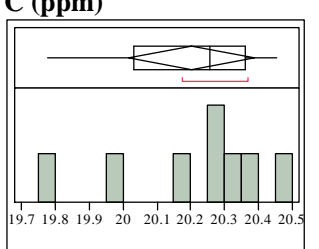

Quantiles

$100.0 \%$ maximum 20.453

$99.5 \% \quad 20.453$

$\begin{array}{ll}99.5 \% & 20.453 \\ 97.5 \% & 20.453\end{array}$

$90.0 \% \quad 20.453$

$75.0 \%$ quartile 20.363

$50.0 \%$ median 20.258

$\begin{array}{lll}25.0 \% & \text { quartile } & 20.031 \\ 10.0 \% & & 19.776\end{array}$

$\begin{array}{ll}2.5 \% & 19.776\end{array}$

$\begin{array}{ll}2.5 \% & 19.776 \\ 0.5 \% & 19.776\end{array}$

$0.0 \%$ minimum 19.776

Moments

Mean 20.201625

Std Dev $\quad 0.2227169$

upper 95\% Mean 20.387821

lower 95\% Mean 20.015429

$\mathrm{N}$

Test Mean=value

Hypothesized Value $\quad 20$

Actual Estimate $\quad 20.2016$

Std Dev

0.22272

t Test
Test Statistic 2.5606

Prob $>|\mathrm{t}| \quad 0.0375$

Prob $>$ t 0.0188

Prob $<\mathrm{t} \quad 0.9812$ 


\section{Distribution:}

\begin{tabular}{|c|c|}
\hline Name: & Location: \\
\hline Sharon Marra & 773-A \\
\hline Connie Herman & 999-W \\
\hline Charles J. Coleman & 773-A \\
\hline Clint Gregory & 773-A \\
\hline Lori Chandler & 773-A \\
\hline Patricia Lee & $703-41 \mathrm{~A}$ \\
\hline Gene Shine & $703-41 \mathrm{~A}$ \\
\hline Damon R. Click & $773-A$ \\
\hline L. Curtis Johnson & 773-A \\
\hline Michael Stone & 999-W \\
\hline David Peeler & 999-W \\
\hline Tommy Edwards & 999-W \\
\hline Kevin Fox & 999-W \\
\hline Fabienne Johnson & 999-W \\
\hline Charles Crawford & $773-42 \mathrm{~A}$ \\
\hline David Best & 999-W \\
\hline John Occhipinti & $704-S$ \\
\hline Jonathan Bricker & 704-27S \\
\hline John Iaukea & $704-30 S$ \\
\hline Aaron Staub & $704-27 S$ \\
\hline Jeff Ray & $704-S$ \\
\hline Robert Hinds & 704-S \\
\hline Terri Fellinger & $704-26 S$ \\
\hline Ryan McNew & 704-S \\
\hline Michael T. Hart & $210-S$ \\
\hline Roger N. Mahannah & $704-28 S$ \\
\hline Michael T. Feller & $704-28 S$ \\
\hline Omar Cardona-Quiles & $704-24 S$ \\
\hline Amanda Shafer & $704-27 \mathrm{~S}$ \\
\hline Mason Clark & $704-27 S$ \\
\hline Helen Pittman & $704-27 S$ \\
\hline Hank Elder & $704-24 S$ \\
\hline Bill Holtzscheiter & $704-15 S$ \\
\hline Pat Vaughan & $773-41 \mathrm{~A}$ \\
\hline
\end{tabular}

